\title{
Initial treatment of combat related limb injuries in Colombia
}

\author{
Manejo inicial de lesiones en extremidades \\ asociadas al conflicto armado en Colombia
}

\begin{abstract}
Alfredo Martínez-Rondanelli1,2, Ana Sofía Arango ${ }^{1}$, Federico Pérsico ${ }^{1}$, Juan Pablo Martínez Cano ${ }^{1,2}$
Suggested citation: Martínez-Rondanelli A, Arango AS, Pérsico F, Martínez JP. Initial treatment of combat related limb injuries in

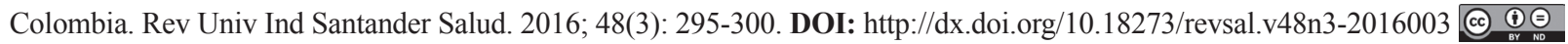

\begin{abstract}
Introduction: Injuries caused by high-energy war weapons are frequent in Colombia. This type of weaponry produces highly complex injuries to the musculoskeletal system that is challenging for health professionals. Objectives: To describe various combat related injuries in Colombia and treatment. Methodology: This is a series of cases from a retrospective cohort including Colombian civilians, police and army personnel wounded in combat areas between January 2012 and March 2013. Demographic variables, injury characteristics, treatment, length of hospital stay, morbidity and mortality were all analysed. Results: 219 patients were admitted, $92 \%$ males $(\mathrm{n}=202)$. Average age was $26 \pm 12$ years. Mechanisms of trauma included explosive devices (44\%), gunshot wounds (36\%) and anti-personnel mines (16\%). Limb injuries were identified in $72 \%(n=159)$. There were 120 soft tissue lesions, 82 limb fractures of which 14 fractures occurred in the spine and pelvis. 34 patients sustained injuries caused by anti-personnel mines, $35 \%$ of whom required limb amputation. Overall $73 \%$ patients were treated at Intensive Care Units (ICU). Mortality rate was 2.7\%. Conclusion: Orthopaedic injuries due to war weapons are complex, require a comprehensive approach, and one or multiple surgical interventions. In our series, mortality rate was low but the severity of the injuries produced permanent disabilities such as limb amputation.
\end{abstract}

Keywords: Orthopedics, military personnel, weapons, war, amputation, fracture, bone.

\section{RESUMEN}

Introducción: Las lesiones de alta energía causadas por armas de guerra son frecuentes en Colombia. Este tipo de armamento produce lesiones muy complejas en el sistema musculoesquelético que son un reto para los profesionales de salud. Objetivos: Describir las lesiones relacionadas con el conflicto armado en Colombia. Metodología: Se trata de una serie de casos a partir de una cohorte restrospectiva que incluye civiles, policías y militares heridos en combate entre Enero 2012 y Marzo 2013. Se analizaron variables demográficas, características de la lesión, tratamiento, tiempo de hospitalización, morbilidad y mortalidad. Resultados: Se admitieron 219 pacientes, 92\% hombres ( $\mathrm{n}=202)$. La edad promedio fue $26 \pm 12$ años. El mecanismo de trauma incluyó explosivos (44\%), heridas por arma de fuego $(36 \%)$ y minas anti-persona (36\%). En $72 \%$ de los casos hubo compromiso de extremidades

1. Fundación Valle del Lili. Cali, Colombia

2. Universidad Icesi. Cali, Colombia

Correspondence: Juan Pablo Martínez Cano. Address: Cra 98 \# 18-49 Consultorio 118, Fundación Valle del Lili, Cali, Colombia. Email: jpmartinezc@gmail.com. Phone number: +5726805757 ext. 7122. 
$(\mathrm{n}=159)$. Hubo 120 lesiones de tejidos blandos y 82 fracturas en extremidades. Además hubo 14 fracturas en columna y pelvis. 34 pacientes tuvieron lesiones por mina anti-persona, de los cuales 35\% requirieron amputación. En general, 73\% requirieron hospitalización en la unidad de cuidados intensivos y la mortalidad fue del $2.7 \%$. Conclusión: Las lesiones ortopédicas por armas de guerra son complejas, requieren un abordaje multidisciplinario y una o más intervenciones quirúrgicas. En esta serie la mortalidad fue baja, pero la severidad de las lesiones produjo discapacidad permanente como es el caso de los amputados.

Palabras clave: Ortopedia, personal militar, armas, guerra, amputación, fractura, hueso.

\section{INTRODUCTION}

The musculoskeletal system is the system most commonly injured with war weapons, accounting for $60-70 \%$ of the war injuries ${ }^{1}$. In the last years, open limb wounds acquired in combat have been increasing in Colombia, as consequence of our long standing political and military conflict.

The severity of injuries due to war weapons in Colombia is similar to those described in world regions where there are wars. These injuries have increased its severity and complexity with the development of more sophisticated weapons such as the cluster bombs. On the other hand, improvements in the rescue and transport of the wounded have resulted in decreased mortality and increased numbers of handicapped population ${ }^{2}$. The consequences can still be catastrophic, including amputation, infection, limb discrepancies, deformities, contractures or limited function of the wounded limb.

Depending on the presentation, the war injuries are classified as primary, secondary, tertiary or miscellaneous ${ }^{1,3,4}$. Primary wounds are caused by the blast that changes the environmental barometric pressure. The organs most affected are lungs, ears, intestines and central nervous system; they are usually lethal. Secondary wounds are produced by flying objects. Tertiary injuries result when people are thrown to the floor or injured by a collapsed structure. Miscellaneous injuries include dust expusure and thermal burns by blast or fire. All of these injuries can compromise the musculoskeletal system.

Hull, et al. studied the mechanism of limb amputations after explosive blasts ${ }^{5}$. Of 100 cases with lethal injuries reviewed, 34 had limb amputation. As a result of their study, the authors developed a computerized model with finite element analysis that recognized the amputation results from a combination of the explosive blast that produces the fracture due to coaxial forces, and then the soft tissue avulsion through the fracture site secondary to dynamic forces. This is shown in Figure 1.

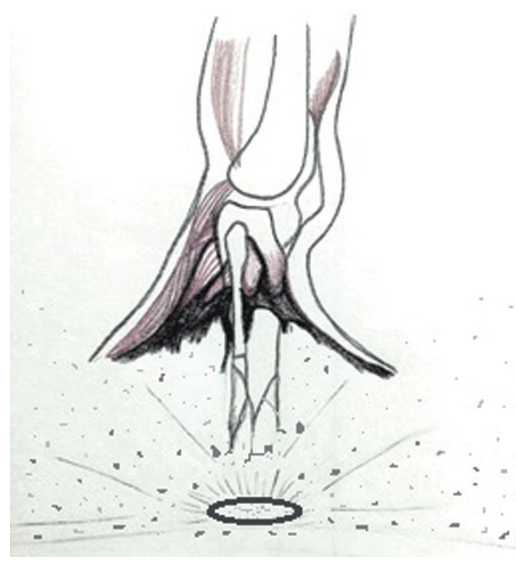

Figure 1. Mechanism of trauma of an explosive device causing leg amputation.

Injuries due to anti-personnel mines exhibit three basic patterns. The first pattern occurs when someone steps on a buried mine and the result is usually foot or leg amputation, as it is shown in Figures 2a and 2b. The second pattern is characterized by random penetrating wounds caused by multiple pieces of a mine that is activated close to the victim. The third pattern results when someone is handling the mine and produces severe injuries on the face and upper extremities ${ }^{1}$.

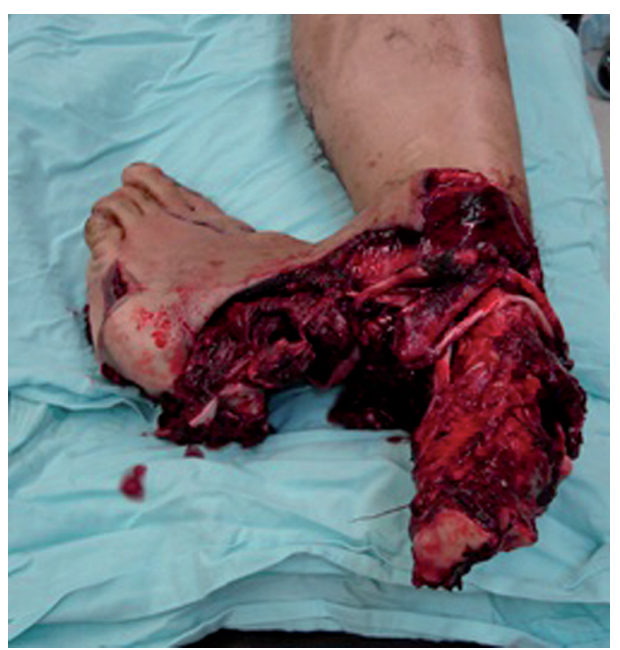

Figure 2a. Anti-personnel mine injuries to the foot of a patient. 


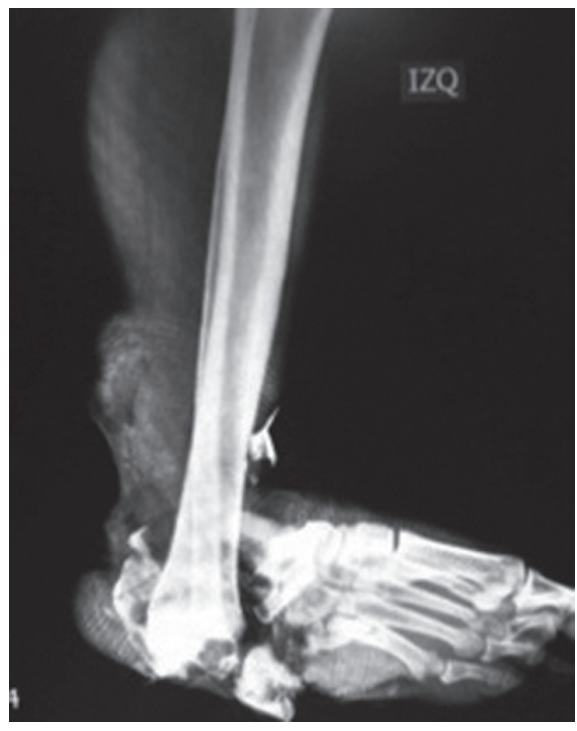

Figure 2b. X-ray showing comminuted fractures of the foot in the same patient.

There are publications about war limb injuries in other parts of the world ${ }^{6-12}$, but none from Colombia or Latin America, where the characteristics of the patients, type of weapons and management may differ. The goal of this study was to describe the socio demographic characteristics of the patients who were admitted to a level I trauma center and evaluate localization, severity and type of injuries, hospital duration, treatment and mortality rate.

\section{MATERIALS AND METHODS}

This study was conducted at Fundación Valle del Lili, a level I trauma center located in Cali, Colombia. It was approved by the ethics committee of the institution. It used data from the Pan-American Trauma Society International Registry, which is routinely filled at our institution since January 2011. This is a general tool that includes all the patients admitted with a traumatic injury. From the total patients admitted with injuries, a selection was made of patients exclusively injured by war weapons from January 2012 to March 2013.

War injuries were defined as those that were inflicted to a civilian, police or army personnel during a combat or while staying in a conflict zone. These injuries could be secondary to different artifacts such as: gunshot, grenade, anti-personnel mines, or other explosive devices.

Data entered included sex and age, time elapsed between trauma and the admission to the hospital.
Patients admitted were classified according to mechanism of trauma, wound anatomic location, its characteristics, and damage inflicted upon soft tissues and bone. It was also described the treatment performed, the ICU stay, and the mortality rate.

Data are presented as frequencies, means, percentages, medians, standard deviations, relative risks and confidence intervals at 95\%. Epi Info 7 and Open Epi 3.01 were used for the statistical analysis.

\section{RESULTS}

\section{Demographic data}

During the 15 months of the study, 538 patients were admitted with injuries secondary to gunshot and explosive devices. Of these, 219 (40.7\%) sustained injuries related to war circumstances and weapons. Incidence was 15 injuries per month. On admission, an average of 5.56 hours (SD 5.34) had passed from the time of trauma occurrence (median 3.67 hours).

202 were men $(92.3 \%)$ and $17(7.7 \%)$ women. Male to female ratio 11.9:1 (CI 95\%: 6.9-22.2); mean age 26 years (range 4-92). There were 42 civilians affected (19\%), 148 army personnel $(68 \%)$ and 29 police members (13\%).

\section{Mechanism of trauma and type of injury}

The most frequent mechanism of trauma was the explosion of a bomb or grenade, 97 patients (44\%), followed by gunshot wounds 80 patients $(36 \%)$, antipersonnel mines $34(16 \%)$ and self-inflicted injuries or injuries inflicted by a fellow combatant, eight cases $(4 \%)$

In 159 patients $(72 \%)$ the injuries affected the limbs. There were 120 soft tissue injuries (59\%) and $82 \mathrm{limb}$ fractures (41\%). Additionally, there were 14 pelvic and spine fractures.

From these 159 patients, 88 (55\%) underwent surgical interventions. The rest were treated with wound dressing and conservative treatment of their fractures in the emergency department.

The incidence of injuries in organs other than limbs included thorax $(28 \%)$, abdomen $(26 \%)$, face $(19 \%)$, skull (8\%), genitalia (4\%), pelvis (4\%), and spine (3\%) (Table 1). 
Salud Vol.48 No.3 Julio - Septiembre de 2016

DOI: http://dx.doi.org/10.18273/revsal.v48n3-2016003

TABLE 1. Injuries with no limb compromise.

\begin{tabular}{lcc}
\hline Location & Number & Percentage \\
\hline Abdomen & 55 & 26 \\
Face & 41 & 19 \\
Spine & 6 & 3 \\
Skull & 18 & 8 \\
Neck & 17 & 8 \\
Genitalia & 9 & 4 \\
Pelvis & 8 & 4 \\
Thorax & 60 & 28 \\
\hline Total & 214 & 100
\end{tabular}

\section{Fractures}

Out of the total number of limb fractures $(\mathrm{n}=82), 29$ were closed (35\%), and 53 open (65\%). 36\% of the open fractures were traumatic amputations $(\mathrm{n}=19), 15$ of those $(79 \%)$ with a vascular injury at admission. In total, 33 patients were admitted with a vascular injury and $45 \%$ required an amputation $(n=15)$ as part of their treatment.

26 fractures occurred in the upper limb (32\%) and 56 in the lower limb (68\%). Hands $(n=12)$ and forearms $(n=7)$ suffered most frequently in the upper extremity. In the lower limb the tibial shaft $(\mathrm{n}=26)$ and femoral shaft $(n=10)$ were the most frequently injured. Fracture distribution is shown in more detail in Table 2. As shown in Figure 3, many patients required staged treatment of their injuries, especially open fractures; in this case an open femur and tibial fracture (floating knee) due to an explosion is shown. Though, most fractures affected the limbs, there were also fractures in other locations: eight pelvic, and six at the thoraciclumbar spine.

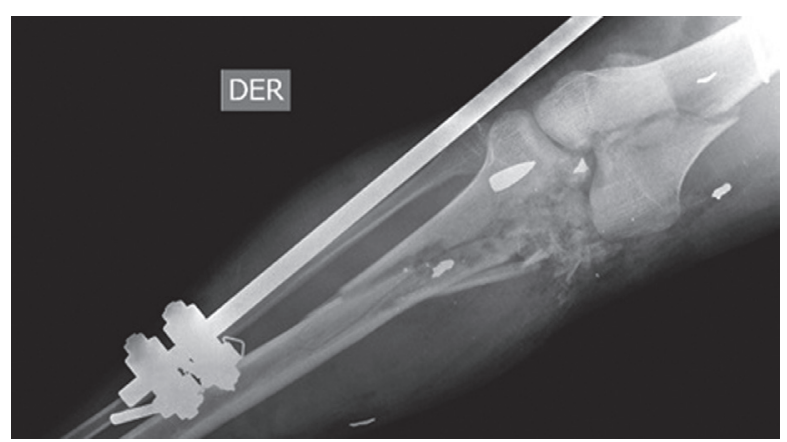

Figure 3a. Open fracture of the distal femur and proximal tibia after a blast explosion. Initial treatment with external fixator.

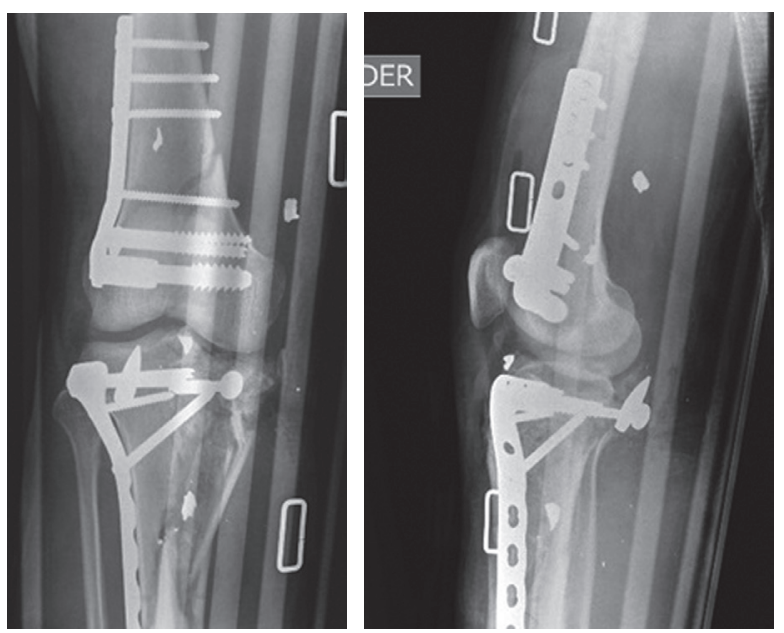

Figure $3 \mathbf{b}$ and $3 \mathbf{c}$. Second stage surgery: open reduction and internal fixation with plates.

TABLE 2. Distribution of limb fractures.

\begin{tabular}{lcc}
\hline Fracture & Number & Percentage \\
\hline Upper extremity & $\mathbf{2 6}$ & \\
\hline Carpal bones & 9 & 34 \\
Clavicle & 2 & 8 \\
Elbow & 1 & 4 \\
Humerus & 2 & 8 \\
Forearm & 7 & 27 \\
Shoulder girdle & 2 & 8 \\
Phalanx & 3 & 11 \\
\hline Lower extremity & $\mathbf{5 6}$ & \\
\hline Hip & 2 & 3 \\
Tibia shaft & 26 & 46 \\
Femur & 10 & 18 \\
Metatarsus/phalanx & 4 & 7 \\
Fibula & 1 & 2 \\
Tibia platteau & 4 & 7 \\
Patella & 1 & 2 \\
Tarsal bones & 1 & 2 \\
Ankle & 6 & 11 \\
Unknown & 1 & 2 \\
\hline
\end{tabular}

\section{Anti-personnel mines}

From 34 patients who suffered this kind of injury (Figure 2a), 35.3\% required amputation $(\mathrm{n}=12)$. On the other hand, from 185 patients admitted with other injuries caused by different mechanisms or types of weapon, only $2.7 \%$ were amputated $(n=5)$. Patients admitted because of anti-personnel mine injuries had a significantly increased risk of amputation over other type of injuries, RR: 13.1 (CI 95\% 4.9-34.7, p<0.001). 


\section{Hospital stay and discharge}

Average hospital stay was $6.7 \pm 21.5$ days. Median stay for those patients with multiple organs involved was two days (0.5-8.5), whereas hospital stay for those with only limb compromise was one day $(0.5-2),(p=0.007)$, $73 \%$ required ICU care $(\mathrm{n}=169)$. The average stay at that unit was $3.8 \pm 18.2$ days (1-254).

Army personnel were transferred to another facility after initial care in $46 \%$ of the cases ( $n=99), 53 \%$ were discharged home $(\mathrm{n}=113)$, and one patient was discharged against medical advice.

\section{Mortality}

Overall mortality rate was $2.7 \%(\mathrm{n}=6)$. All were men. Five were military personnel $(83 \%)$ and one was a civilian. Median Injury Severity Score (ISS) for survivors was 5 (3-14), and the ISS for the deceased was 63 (38-73), with a significant difference between groups, $\mathrm{p}<0.001$.

\section{DISCUSSION}

Improved description of war related orthopaedic injuries cared for in a reference center contributes to increase our knowledge of the natural history of these patients, including their prognosis and responses to the treatments given. In the same way, institutions can be better prepared for those situations, optimizing their resources.

From the results, it was shown that patients seen at our institution arrive to the hospital after at least five hours from the moment of the injury. This is explained by difficulties of access to the combat zones, and their remoteness to the reference hospitals in Colombia. Most of the times the war scenarios are located in the forest or jungle and patients have to be transported in helicopters. These five hours are excessive and could negatively impact the end result. It is desirable to lower this reaction time or to implement mobile army surgical hospitals that may give a faster, more adequate response. This is a huge challenge given the geographical characteristics of Colombia.

One fifth of the wounded patients were civilians, a very high number for these injuries classified as war related. This reveals the nature of Colombian conflict, which affects mainly rural, isolated populations where combatants can transgress laws more easily.
From 34 patients wounded with anti-personnel mines, twelve lost a lower limb. The odds of ending up in an amputation are as high as 35\% when the weapon used was an anti-personnel mine. This is because of the high energy of this type of weapon and its association to vegetal contamination that increases the risk of infection.

$73 \%$ of combat related injured patients required ICU care. This reflects the severity of the injuries, the systemic derangement, and hemodynamic instability that may affect most of these patients. A multidisciplinary treatment can reduce mortality in these patients. Nevertheless, such mortality rate can be subestimated since patients with most severe injuries might have died shortly after trauma or during transportation.

It is expected that patients with only orthopaedic affectation may recover faster from the injuries and be discharged sooner than those with injuries that implicated organs other than their limbs. Patients with injuries limited to their limbs, were released earlier form the hospital than those with multisystem injuries, especially in abdomen or brain.

\section{CONCLUSION}

Combat related injuries and their treatment are a complex challenge for the orthopaedic surgeon. They can generate permanent functional impairment such as happens with amputations or they can be life threatening. That is the main reason why the management of these patients requires a multidisciplinary approach. During the initial phases of treatment, members of health teams medical staff should prioritize reanimation and damage control. Orthopaedic treatment should include debridement, curettage and lavage; the wounds should be left open. Definite treatment should be staged once infection is controlled or ruled out, and rehabilitation should start early. Mangled extremity severity score (MESS) is helpful in the decision-making process for amputations. Closed fractures or open fractures with small wounds can be fixed early. Open fracture Gustilo III and those with frank contamination, will require external fixation for damage control. Traumatic amputation should be carried out at high level, in a clean area, and should have proper soft tissue cover, to decrease the probability of infection and enhance healing.

\section{CONFLICT OF INTEREST}

There are not conflict of interest to report. 


\section{REFERENCES}

1. Covey DC. Blast and fragment injuries of the musculoskeletal system. J Bone Joint Surg Am. 2002; 84A(7): 1221-1234.

2. Mikovic M, Golubovie Z. War wounds caused by cluster bombs - Nature and results of treatment. Facta Universitatis 2000; 7(1): 86-90

3. Leibovici D, Gofrit ON, Stein M, Shapira SC, Noga Y, Heruti, et al. Blast injuries: bus versus open-air bombings. A comparative study of injuries in survivors of open-air versus confined-space explosions. J Trauma .1996; 41(6): 1030-1035.

4. Stapczynski JS. Blast injuries. Ann Emerg Med. 1982; 11(12): 687-694.

5. Hull JB, Cooper GJ. Pattern and mechanism of traumatic amputation by explosive blast. J Trauma. 1996; 40(3 Suppl): S198-205.

6. Mack AW, Freedman BA, Groth AT, Kirk KL, Keeling JJ, Andersen RC. Treatment of open proximal femoral fractures sustained in combat. $\mathrm{J}$ Bone Joint Surg Am. 2013; 95(3): e13(1-8). DOI: 1 0.2106/JBJS.K.01568.

7. Kacar H, Delibegovic S. Treatment of war injuries of the extremities using primary osteosynthesis and using closure of wound with drainage system. BH Surgery. 2012; 2: 18-24.

8. Seng VS, Masquelet AC. Management of civilian ballistic fractures. Orthop Traumatol Surg Res. 2013; 99(8): 776-781. DOI: 10.1016/j.otsr.2013.08.005.

9. Mathieu L, Bazile F, Barthélémy R, Duhael P, Rigal S. Damage control orthopaedics in the context of battlefield injuries: the use of temporary external fixation on combat trauma soldiers. Orthop Traumatol Surg Res. 2011; 97(8): 852-859. DOI: 10.1016/j.otsr.2011.05.014.

10. Tintle SM, Baechler MF, Nanos GP, Forsberg JA, Potter BK. Reoperations following combat-related upper-extremity amputations. J Bone Joint Surg Am. 2012; 94(16): e1191-1196.

11. Bosse MJ, Ficke JR, Andersen RC. Extremity war injuries: current management and research priorities. J Am Acad Orthop Surg. 2012;20 Suppl 1: VIII-X. DOI: $10.5435 / J A A O S-20-08$-viii.

12. Ficke JR, Pollak AN. Extremity war injuries: development of clinical treatment principles. J Am Acad Orthop Surg. 2007; 15(10): 590-595. 